\title{
Forensic Browser on Line Messenger Services for Handling Cyberfraud using National Institute of Standard Technology Method
}

\author{
Mifthahul Jannah \\ Department of Information System \\ Universitas Ahmad Dahlan \\ Yogyakarta of Indonesia
}

\author{
Imam Riadi \\ Department of Information System \\ Universitas Ahmad Dahlan \\ Yogyakarta of Indonesia
}

\begin{abstract}
Advances in information and communication technology play an important role in everyday life which is useful for interacting with one another. each other and make it easier for humans to do some work. Line Messenger is an online chat application that sends a text message in real-time, in addition to text messages, other features of the Line messenger application are audio files, videos, and also photos or images using the internet network with the number of users reaching 217 million in 2016. Cyberfraud is a new type of fraud that uses modern cyber information technology, and its essence is still a fraud crime. This study will use a scenario about the Cyberfraud case from a conversation using an instant messenger application, namely Line which runs on the Chrome web browser using the NIST (National Institute of Standards and Technology) stages. This study uses several forensic tools in finding the digital evidence needed including namely FTK Imager, Belkasoft, Browser History Capturer, Browser History Viewer, and Browser History Examination. Digital evidence found in Belkasoft and FTK Imager was $60 \%$ with digital evidence of conversation text, Email, and account ID. In Browser History Capturer andBrowser History Viewer as much $40 \%$ with digital evidence Photos and Links. Furthermore on Browser History Capturer and Browser History Examiner tools as much as $40 \%$ with digital evidence in the form of Links and Cached Web.
\end{abstract}

\section{Keywords}

Cyberfraud, Line Messenger, NIST, Forensics, Browser

\section{INTRODUCTION}

Technological advances Information and communication play a very important role in everyday life that is useful for interacting with each other and making it easier for humans to do some work [1]. Social media can disseminate all forms of information very quickly by sharing content in the form of videos, photos, and accompanied by interesting captions to support an upload on social media [2]. Line Messenger is an online chat application that sends a text message in real-time, in addition to text messages, other features of the Line messenger application are audio files, videos, and also photos or images using the internet network.[3]. Social media itself is very fast in spreading information without a filter before uploading it, therefore social media users must be smarter in using social media, but in fact, there are still many social media users who are easily fooled by accounts that are not clear, such incidents are categorized as Cyberfraud. To find digital evidence, techniques or stages are needed, in this study, the stages used are NIST (Collection, Examination, Analysis, and Reporting) [4].

\subsection{Study Literature}

\subsubsection{Previous Study}

Mulia Fitiana, khairan AR, and Jiwa Malem Masya (2020) entitled "Application of the National Institute Of Standard and Technology (NIST) method in Digital Forensic Analysis for Handling Cybercrime". In this study using the WhatsApp application on an android cellphone with pornography cases, the tools used to find evidence are KingRoot to root the smartphone, CWM (ClockworkMod) Recovery, FTK Imager to perform data imaging, WhatApp viewer to describe the WhatsApp database that has been described. , and DB Browser for SQLite to open the wa.db folder to view the contact list on the smartphone. The evidence found as a result of the research is in the form of chats that have been deleted by the perpetrator and the contacts found on the perpetrator's smartphone [5].

Rauhulloh Ayatulloh Khomeini Noor Bintang, Rusydi Umar, and Anton Yudhana (2020) entitled "Analysis of Facebook Lite Social Media with Forensic Tools Using the NIST Method". The case contained in the research is posting hate speech on social media facebook lite, the tool used in conducting investigations, namely MOBILedit forensic pro to extract data from smartphones, to find the perpetrator's account by cloning the data so that it is a string value or original data. The evidence that was found in the study were 297 images with different sizes, filenames, widths, and 19 videos with different types of filename, path, size, modified [6].

Gregorius Hendita Artha Kusuma and Yusuf Fadhilah (2019) with the research title "E-Commerce Digital Forensic Analysis on Car Rental Websites Using the NIST Method". Cases that identify cybercrimes who use e-commerce websites by offering unreasonable prices on car rental services. The online tools used in the research are whoisdomaind.tools, ScamAdviser and statshow to view the address of the perpetrator via google map. Based on the results of website research on rental services that were examined after checking through the Scam Adviser tools, the eligibility to visit the website was only $58 \%$ and there was no online reputation, other evidence found in the IP research location was in the US but having an address in Yogyakarta [7].

Muhammad Abdul Aziz, Imam Riadi and Rusyi Umar (2018) with the research title "Forensic Analysis of Web-based Line Messenger Using the National Institute Of Justice (NIJ) Framework". The results of this research were obtained using the FTK Imager and SQLite tools by exploring the laptop 
directory used as research to find the Line Messenger database in the Google Chrome browser which contained files and folders such as caches and logs [8].

Muhammad Irwan Syahib, Imam Riadi, and Rusydi Umar (2018) entitled "Digital Forensic Analysis of Beetalk Applications for Cybercrime Handling Using the NIST Method". The case in this study is Cybercrime, a forensic tool used by MOBILedit, OXIGEN Forensics, and Kingroot. The evidence found in this research is evidence of conversations between accounts A and account B, and photo caches [9].

\subsubsection{Digital Forensics}

Forensics is a science related to cyber law (cyberlaw), security or security on systems, and computer networks [10]. Digital forensics can be interpreted as a part of forensic science that covers the discovery and investigation of material (data) found on digital devices [11]. Digital Forensics basically can find digital evidence that is usually stored on temporary computer/mobile storage, permanent storage, USB, CD, network traffic, and others [12]. Digital Forensics is the application of science and computer technology for projustice, which in this case is proving high-tech crimes or computers scientifically to be able to obtain digital evidence that can be used against violators [13].

\subsubsection{Web Browser}

Web Browser is a tool to perform various activities on the Internet by users. Users utilize browsers for various functions such as information retrieval, access to email accounts, ecommerce, banking creation, instant messaging, online blogs, access to social networks. Web browsers log a lot of data related to user activity. Information such as URLs visited by users, search terms, cookies, cache files, access times, and usage times are stored in memory on the system [14]. Web Browsers are diverse, with each having its characteristics. This allows users to choose their favorites or try different Web browsers at the same time. In this situation, it is difficult to trace the Web sites the user has visited if the forensic investigator can only analyze the log files of a particular Web browser [15].

\subsubsection{Digital Evidence}

Evidence is data information contained in an electronic device that will later be acquired to obtain digital evidence, examples of physical devices can be laptops, smartphones, and so on. The information obtained from the acquisition is what is called evidence [16]. Digital evidence can be found in the physical evidence is electronic which can be identified concretely so that the physical evidence can be acquired [17].

\subsubsection{Line Messenger}

Line Messenger is an instant messenger application by sharing interesting features, namely text conversation features, video calls, voice notes, and being ability to send an image using the internet network in real-time [18]. Line Messenger users reach 217 million worldwide according to static data from the business of APPS website, the many users of Line messenger do not deny that internet crimes will occur, such as fraudulent buying and selling of goods online, means of buying and selling drugs or even frequent cyberbullying. occurs in adolescents who make mental down and are not confident [19].

\subsubsection{Cybercrime}

Cybercrime is anything that uses the internet network that aims to commit criminal acts using very sophisticated technology with the motive of abusing technology to reap the benefits of losses obtained from other people [20]. Crimes on social media or cybercrime are very different from crimes that occur in person, the effect of cybercrime is very significant on victims [21]. Detailed cybercrimes (which victims think are genuine) are a major problem. Despite the existence of a body of relevant laws passed down by harmonization around the world and bargaining appointments with the police, the attributes of cybercrimes are severe enough to be announced, plots to hinder the customary investigation process [22].

\subsubsection{Cyberfraud}

Cyberfraud (also referred to as cyber-scams) is any type of fraud that exploits mass communication technologies (eg email, Instant Messenger, social networking sites) to trick people into spending money [23]. User of telecommunications and network technology is involved in the process of cyber fraud. Exploring the concept of Cyberfraud should also explain the concepts of telecommunication fraud and network fraud [24].

\subsubsection{National Institute of Standard Technology}

National Institute of Standard and Technology (NIST) provides a standardized method that can be used to solve problems and analyze digital evidence or the steps to obtain information from digital evidence [25]. National Institute of Standard and Technology (NIST) to obtain evidence related to electronics and digital, it has 4 stages as shown in Figure 1.

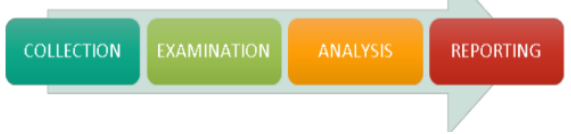

Figure 1. Stages of NIST

1. Collection

Collection stage is the initial stage that used to identify and acquire physical evidence in the form of electronic and digital media related to criminal acts.

2. Examination

This stage is a step to extract data that has been generated from the collection process, the resulting data will be extracted automatically by forensic applications or can be done manually.

3. Analysis

Analysis is a step taken to identify the extracted data, the analysis is carried out by the applicable rules without violating the rules.

4. $\quad$ Reporting

The process reporting is a step to report the results of the steps that have been done previously, the documented report should be written in its entirety and detail.

\section{METHODOLOGY}

\subsection{Research Scenario}

scenarios are needed to support this research, the scenario discusses how the stages that occur in browser forensics take place. 


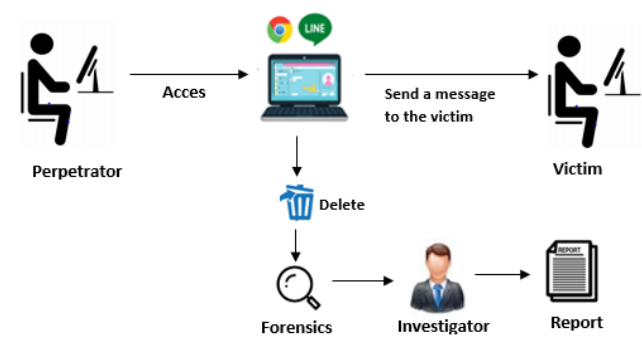

Figure 2. Research Scenario

Figure 2 Perpetrator using a laptop that has installed the chrome web browser and the Line Messenger extension on the chrome browser. Perpetrator send messages that trigger actions Cyberfraud. The victim asked the police for help by bringing a screenshot of the conversation between the victim and the perpetrator, the police formed a special team to resolve the case and arrest the perpetrator. When the police arrested the perpetrator, the police secured evidence at the crime scene, namely a laptop that was still faulty which was accessing Line Messenger on the chrome web browser where the perpetrator had deleted the chat history between the perpetrator and the victim.

\subsection{Research Stages}

This research uses stages based on the stages of the National Of Standards and Technology (NIST) which are carried out by live forensics. NIST has 4 stages, namely, Collection, Examination, Analysis, and Reporting.

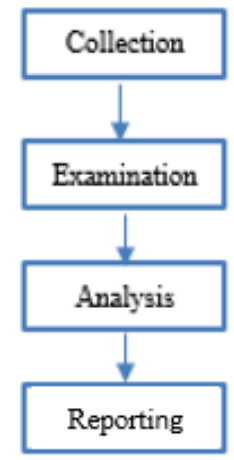

Figure 3. Stages of Implementation

Figure 3 is the investigator's stage in finding digital evidence. The following is an explanation of the implementation stages:

\subsubsection{Collection}

The collection stage is the stage of searching for data and information by investigators, as well as collecting evidence obtained at the crime scene (TKP). In this research, the evidence used is a laptop that is used by the Perpetrator to commit internet crimes. Information on physical evidence found in the research case scenario can be seen in table 1 .
Table 1. Physical Evidence

\begin{tabular}{|c|c|c|c|}
\hline No & Evidence & Figure & Description \\
\hline 1 & $\begin{array}{c}\text { Laptop of } \\
\text { perpetrator }\end{array}$ & $\begin{array}{l}\text { Laptop used by } \\
\text { the perpetrator is } \\
\text { branded Lenovo } \\
\text { B41-35, the } \\
\text { laptop was found } \\
\text { in a crime scene } \\
\text { and connected to } \\
\text { Internet. }\end{array}$ \\
\hline $\mathbf{2}$ & $\begin{array}{c}\text { Charger } \\
\text { Laptop } \\
\text { ofperpetrat } \\
\text { or }\end{array}$ & $\begin{array}{l}\text { Charger used } \\
100-240 \text { V input } \\
\text { and 20V output. }\end{array}$ \\
& & \\
\hline
\end{tabular}

Table 1 is the documentation of physical evidence used by the perpetrator in committing a crime found at the location of the case.

\subsubsection{Examination}

Examination stage is the main stage in conducting an investigation, at this stage data acquisition will be carried out on physical evidence in the form of a laptop to obtain data and information on the perpetrator's crime.

\subsubsection{Belkasoft RAM Capturer}

Belkasoft Live RAM Capturer is a forensic tool used to perform data acquisition on RAM on electronic evidence belonging to the perpetrator namely a laptop.

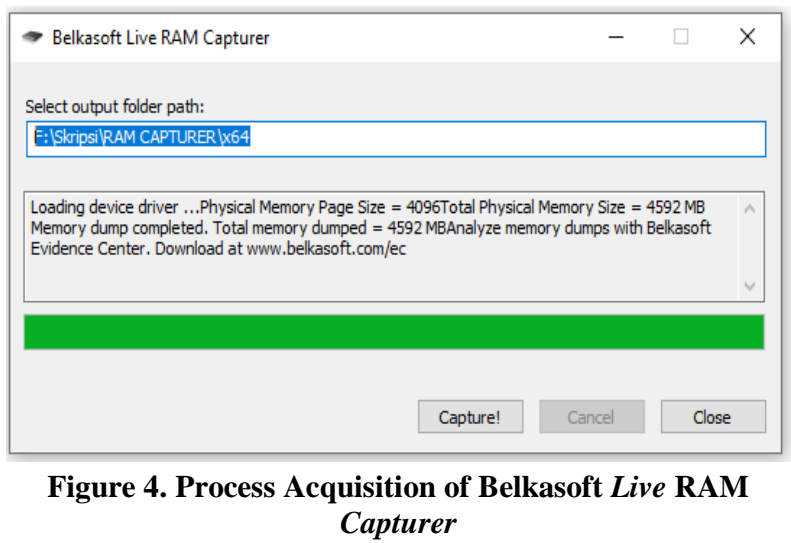

Based on Figure 4, the results obtained from the Belkasoft Live RAM Capturer tool are in the form of files with .mem extensions.

\subsubsection{FTK Imager}

FTK imager is used to perform imaging on files that have been obtained from the acquisition of RAM. 


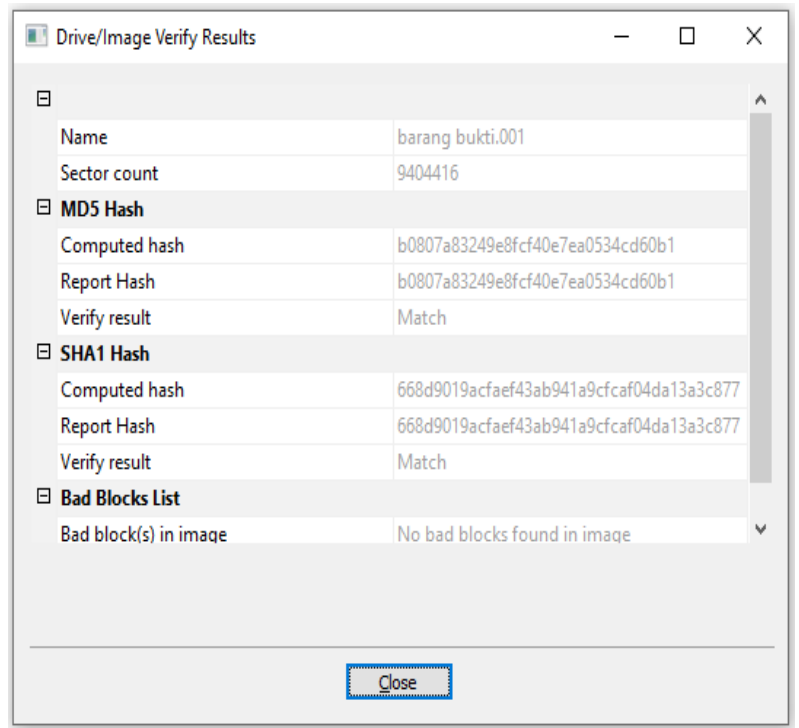

Figure 5. Hashing Results

Figure 5 shows the hashing results between MD5 and SHA1 files. The hash value from the two filematches which means that there is no change in the data.

\subsubsection{Browser History Capturer}

Browser History Capturer is used to acquire data on web browsers used by Perpetrator to commit internet crimes. Data obtained from browser acquisition can be in the form of web browsing history, cache, and archived history.

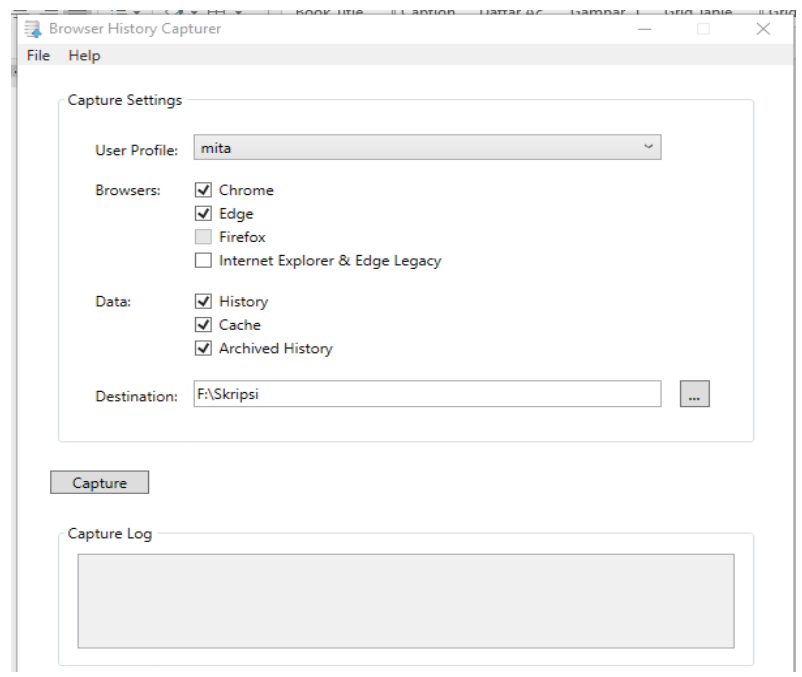

Figure 6. Process Acquisition of Browser History
Capturer

Figure 6 shows that these tools can only be used on Chrome, Edge, Firefox, and Internet Explorer \& Edge legacy web browsers, so they are not suitable for use by Macbook users who usually use the Safari web browser.

\subsubsection{Analysis}

Analysis is the stage of investigators to analyze data and information that has been obtained previously in order to obtain the required digital evidence. The results at this analysis stage will later be entered into the reporting table to see the differences in the results of several tools used in this research.

\subsubsection{FTK Imager}

Data obtained from the capture using the Belkasoft live RAM capturer with the .mem format which can be seen in Figure 7.

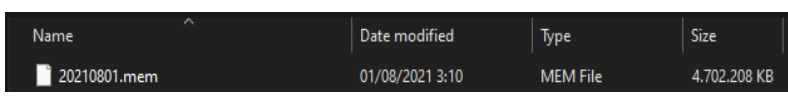

Figure 7. Belkasoft Live RAM Capturer Result

The acquired file in Figure 7 will then be analyzed using the FTK imager in collecting data and information. will be used as digital evidence. to make it easier for investigators to search for investigator data using keywords or parameters to be searched.

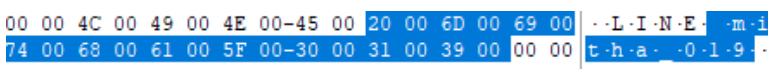

Figure 8. Id Line of Perpetrator

Based on Figure 8, investigators managed to find the ID of the perpetrator was "mitha_019" which was used to deceive the victim according to the screenshot evidence provided by the victim to report the crime that had been committed by the perpetrator. The perpetrator's id is important information that will be used as digital evidence

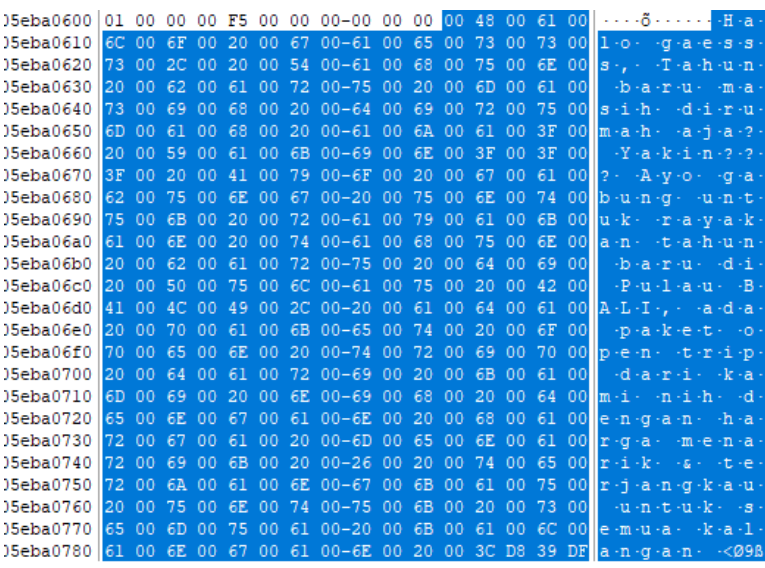

Figure 9. Evidence of Conversation 1

Figure 9 shows evidence of the first conversation that took place between the perpetrator and the victim which contained an offer of vacation tickets with, the sentence is similar to the screenshot given by the victim.

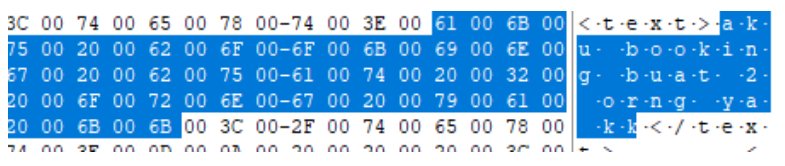

Figure 10. Evidence of Conversation 2

Figure 10 is a reply to a message from the victim to the perpetrator that the victim booked a ticket with a total of 2 people.

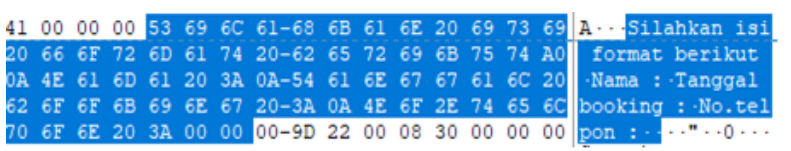

Figure 11. Evidence of Conversation 3 
Figure 11 The perpetrator asks the victim to fill in the data format in the form of a name, booking date, and telephone number so that the mode of carrying out an action that refers to cyberfraud can run smoothly.
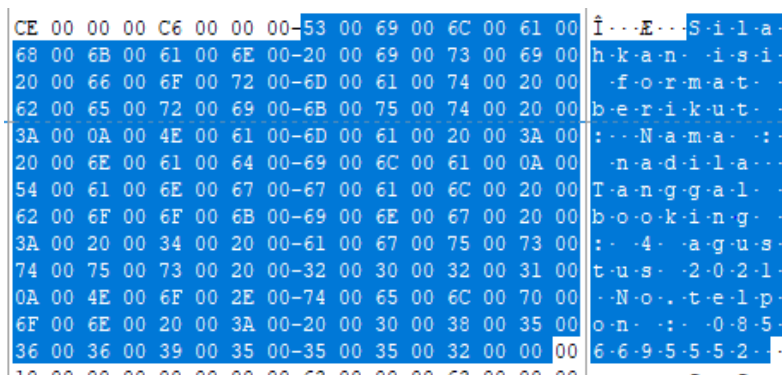

Figure 12. Evidence of Conversation 4

Figure 12 the victim is tempted by the perpetrator's offer, then the victim fills in the data ordered by the perpetrator where the data contains the name of the victim, namely Nadila, booking date 4 August 2021 andTelephone Number “0856695552".

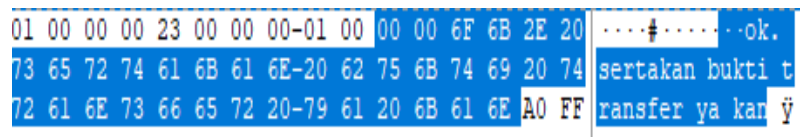

\section{Figure 13. Evidence Conversation 5}

Based on Figure 13, the evidence found by the perpetrator was in the form of a text sent by the perpetrator to the victim to immediately transfer the money.

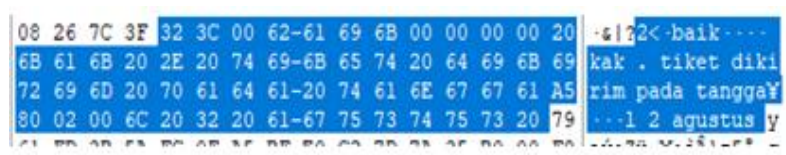

Figure 14. Evidence of Conversation 6

Based on Figure 14, the perpetrator sent a message to the victim that the perpetrator would send a ticket on August 2 after making a payment transaction.

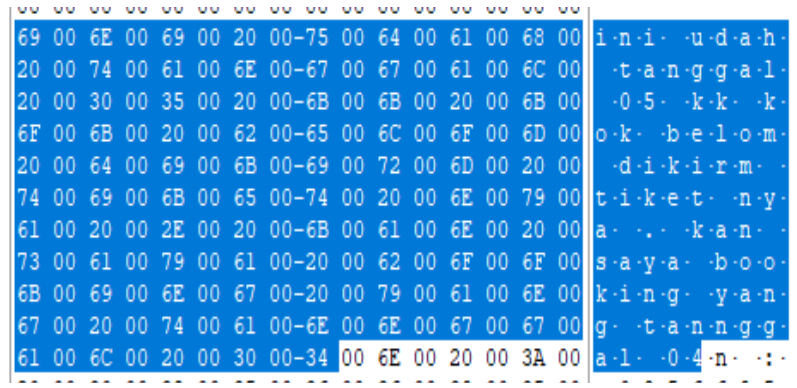

Figure 15. Evidence of Conversation 7

Based on the conversation obtained in Figure 15 the victim felt cheated because the perpetrator initially promised the victim a ticket on August 2, but after arriving on August 5, the victim did not get the ticket that had been ordered. The victim felt aggrieved because the victim had transferred some money to buy the ticket.

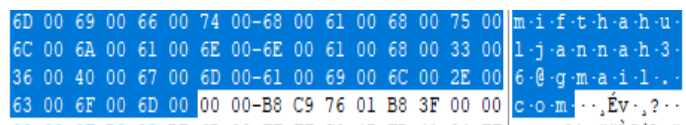

Figure 16. Email of the perpetrator
Figure 16 is the email of the perpetrator used to $\log$ in to the Line messenger account. The perpetrator's email name is mifthahuljannah36@gmail.com.

\subsubsection{Browser History Viewer}

Brower History Viewer is a tool that is used to read the results of the data obtained when the browser captures using the History Capturer browser tools. Information and data that can be found using this tool can be in the form of browsing history and cached images that have been accessed by Perpetrator which can be analyzed into digital evidence.

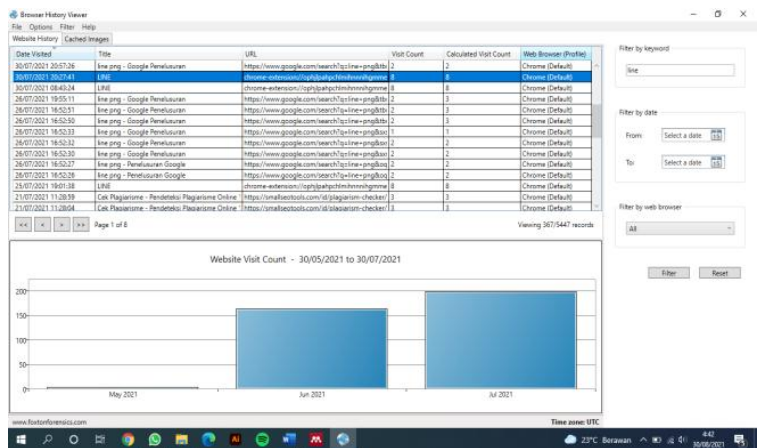

Figure 17. History web with the keyword LINE

Figure 17 shows the evidence obtained in the form of history when the perpetrator logged in to the perpetrator's Line account through the Chrome web browser, and several other activities that the perpetrator had traced in the perpetrator's browser history.

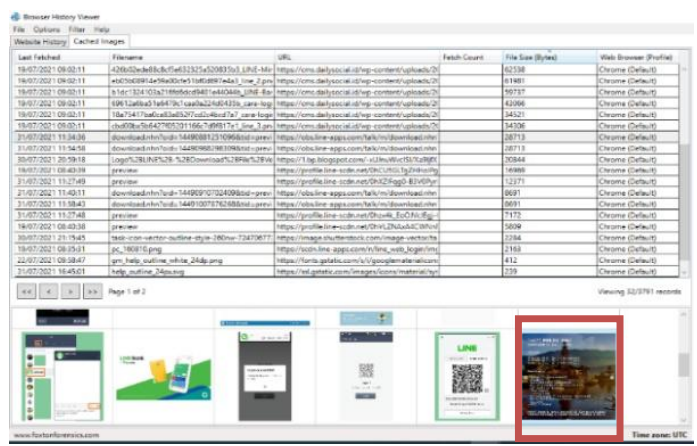

Figure 18. Photo cache from LINE

Figure 18 shows evidence of promotional images that have been sent by the perpetrator using Line messenger running on google chrome on 31 months 072021 at 11:34:36 which can be used as digital evidence so that the police can follow up on Internet crimes that have been committed by the Perpetrator.

\subsubsection{Browser History Examiner}

Browser history examination is a tool used by investigators to read results from browser capture to display digital evidence. In this tool, the information or data that will be obtained can be in the form of bookmarks, browser settings, caches files, cache images, cached web pages, cookies, downloads, email addresses, favicons, from history, logins, searches, session tabs, thumbnails, and website visits. 


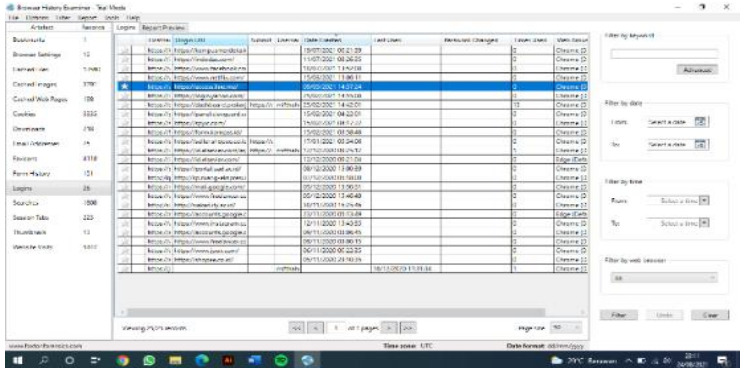

Figure19. History Login

Figure 19 is a history of logins that have been carried out by the perpetrator, the blue bar is digital evidence that the perpetrator has logged in to a LINE account via the chrome web browser.

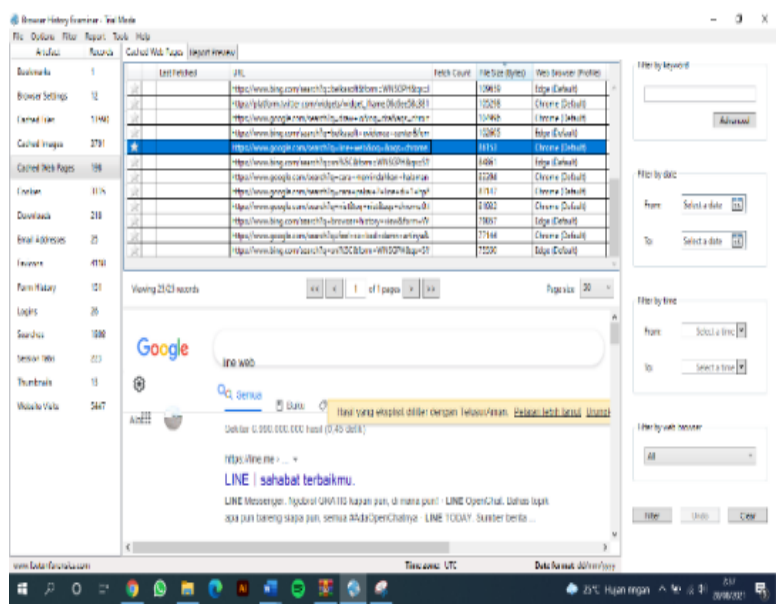

Figure20. Caches Web Pages

Figure 20 are the findings of cached web pages that have been visited by the perpetrator, based on the image above, the perpetrator has searched Line Messenger through the chrome browser with a file size of 86153 bytes.

\subsubsection{Reporting}

Reporting is the last stage of the National Institute of Standards and Technology (NIST) stage. At this stage, the investigator will make a report from the results obtained during an investigation of the evidence found at the crime scene (TKP), namely physical evidence in the form of a laptop where the perpetrator uses a chrome web browser to carry out internet crimes according to the scenario described. already made. At the reporting stage, it is a report of the results of the tools that have been used to find data and information about crimes committed by the Perpetrator. The following are the specifications of the evidence that can be seen in Table 2.

Table 2. Specifications of Physical Evidence

\begin{tabular}{|c|l|l|}
\hline NO & Nama & Keterangan \\
\hline 1. & Processor & AMD A6-7310 APU @ 2,2 Ghz \\
\hline 2. & Graphics & AMD Radeon ${ }^{\text {TM }}$ R Graphics \\
\hline 3. & Memory & 4 Gb DDR3 \\
\hline 4. & Hardisk & 500 GB SATA \\
\hline 5. & Monitor & 14 Inch \\
\hline 6. & OS & Windows 10 Pro \\
\hline
\end{tabular}

The results of the data found from the acquisition of RAM in carrying out the stages of browser forensics on chrome were carried out by the live forensic method. The results of the data found to be used as digital evidence can be in the form of interaction information between the victim and the perpetrator such as the message content, the perpetrator's account id, and the account password of the perpetrator, that can be seen in Table 3.

Table 3. Data Results Found

\begin{tabular}{|c|c|c|}
\hline Information & Source & Content \\
\hline Email & Perpetrator & $\begin{array}{l}\text { mifthahuljannah36@gmail.c } \\
\text { om }\end{array}$ \\
\hline Id Akun & Perpetrator & mitha_019 \\
\hline Text & Perpetrator & $\begin{array}{l}\text { Hallo gaess, Tahun baru } \\
\text { masih dirumah aja? } \\
\text { Yakin??? Ayo gabung untuk } \\
\text { rayakan tahun baru di Pulau } \\
\text { BALI, ada trip dari kami nih } \\
\text { dengan harga menarik \& } \\
\text { terjangkau untuk kalangan } \\
\text { booking seat'mu segera } \\
\text { karena kouta terbatas gaess }\end{array}$ \\
\hline Text & Victim & $\begin{array}{l}\text { Aku booking buat } 2 \text { orng ya } \\
\text { kk }\end{array}$ \\
\hline Text & Perpetrator & $\begin{array}{l}\text { Silahkan isi format berikut } \\
\text { Nama: } \\
\text { Tanggal booking: } \\
\text { No.Telpon: }\end{array}$ \\
\hline Text & Victim & $\begin{array}{l}\text { Silahkan isi format berikut } \\
\text { Nama: Nadila } \\
\text { Tanggal booking: } 4 \text { agustus } \\
2021 \\
\text { NO.Telpon: } 085764808269\end{array}$ \\
\hline Text & Perpetrator & $\begin{array}{l}\text { ok. Sertakan bukti transfer } \\
\text { ya kan }\end{array}$ \\
\hline Text & Perpetrator & $\begin{array}{l}\text { baik kak. tiket dikirim pada } \\
\text { tanggal } 2 \text { agustus ya }\end{array}$ \\
\hline Text & Perpetrator & $\begin{array}{l}\text { Ini udah tanggal } 05 \text { kk kok } \\
\text { belom dikirim tiketnya kan } \\
\text { saya booking tanggal } 04\end{array}$ \\
\hline Picture & Perpetrator & 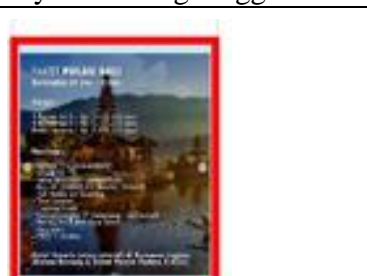 \\
\hline
\end{tabular}

Based on Table 3, the evidence found from this research is the perpetrator's account ID, email, the text of the conversation between the perpetrator and the victim, and photos sent by the victim.

\subsubsection{Result}

Results found in this study in the form of image uploads that were sent by the perpetrator were found in the Browser History Capturer and Browser History Viewer tools, while the text of the conversation between the perpetrator and the victim was found using the Belkasoft and FTK Imager tools, where Belkasoft was used to acquire RAM. on the laptop and the FTK Imager is used to read the results of the RAM acquisition that has been obtained. In the Browser History 
Capturer and Browser History Examiner tools, researchers only find evidence according to the scenario in the form of a web page browsing history link and account login.

Table 4. Comparison of Results obtained from Several Tools

\begin{tabular}{|c|l|c|c|c|}
\hline \multirow{2}{*}{ No } & \multirow{2}{*}{$\begin{array}{l}\text { Information } \\
\text { Data }\end{array}$} & \multicolumn{3}{|c|}{ SoftwareForensic } \\
\cline { 3 - 5 } & $\begin{array}{c}\text { Belkas } \\
\text { oft \& } \\
\text { FTK } \\
\text { Imager }\end{array}$ & $\begin{array}{c}\text { Browser } \\
\text { History } \\
\text { Capturer } \\
\& \\
\text { viewer }\end{array}$ & $\begin{array}{c}\text { Browser } \\
\text { History } \\
\text { Capturer } \\
\& \\
\text { examiner }\end{array}$ \\
\hline 1. & Link & $\boldsymbol{V}$ & $\boldsymbol{V}$ & $\checkmark$ \\
\hline 2. & Photos & - & $\boldsymbol{V}$ & - \\
\hline 3. & $\begin{array}{l}\text { Conversation } \\
\text { Text }\end{array}$ & $\boldsymbol{V}$ & - & - \\
\hline 4. & Account Id & $\boldsymbol{V}$ & - & - \\
\hline 5. & $\begin{array}{l}\text { Cached Web } \\
\text { Pages }\end{array}$ & - & - & $\checkmark$ \\
\hline
\end{tabular}

Based on the results of Table 4, the evidence found using several tools forensic. Uploaded images that have been sent by the perpetrator have been found in the tools Browser History Capturer and Browser History Viewer, while the text of the conversation between the perpetrator and the victim has been found using the tools Belkasoft and FTK Imager, where Belkasoft is used to acquire RAM on the laptop and FTK Imager is used to read the results of the acquisition of RAM that has been obtained. In the tools, the Browser History Capturer and Browser History Examiner researcher only finds evidence according to the scenario in the form of a web page browsing history link and account login.

\section{CONCLUSION}

Digital forensic evidence for handling Cyberfraud using the chrome web browser is obtained by acquiring live forensic RAM on the perpetrator's laptop, digital evidence obtained in this study is in the form of text, cache, history or history of web pages that have been visited by the perpetrator while using the goods. physical evidence in the form of a laptop belonging to the perpetrator. Web browser usage activities recorded on the RAM of a laptop are volatile or temporary, where data will be lost if the device is not connected to power or turns off, so in this research forensics is carried out live to find data on the perpetrator's laptop to be used as evidence of a case. electronic crimes that often occur today. The results of the evidence carried out with the NIST stage assisted by several tools forensicwere found in this study where the results from Belkasoft and FTK Imager were $60 \%$ with digital evidence of conversation text, Email, and account ID, Browser History Capturer and Browser History Viewer as many as $60 \%$. $40 \%$ with Photo and Link digital evidence. Furthermore, the Browser History Capturer and Browser History Examiner tools are also $40 \%$ with digital evidence in the form of links and Cached Web Pages.

\section{REFERENCES}

[1] D. A. González-Padilla and L. Tortolero-Blanco, "Social media influence in the COVID-19 pandemic," Int. Braz J Urol, vol. 46, no. Suppl 1, pp. 120-124, 2020, doi: 10.1590/S1677-5538.IBJU.2020.S121.

[2] A. Yudhana, I. Riadi, and I. Zuhriyanto, "Analisis Live Forensics Aplikasi Media Sosial Pada Browser
Menggunakan Metode Digital Forensics Research Workshop (DFRWS)," J. TECHNO, vol. 20, no. 2, pp. 125-130, 2019.

[3] A. Fauzan, I. Riadi, and A. Fadlil, "Analisis Forensik Digital Pada Line Messenger Untuk Penanganan Cybercrime," Annu. Res. Semin., vol. 2, no. 1, pp. 159163, 2017, [Online]. Available: http://seminar.ilkom.unsri.ac.id/index.php/ars/article/vie w/832/752.

[4] D. T. Yuwono, A. Fadlil, and S. Sunardi, "Performance Comparison of Forensic Software for Carving Files using NIST Method," J. Teknol. dan Sist. Komput., vol. 7, no. 3, pp. 89-92, 2019, doi: 10.14710/jtsiskom.7.3.2019.8992.

[5] M. Fitriana, K. A. AR, and J. M. Marsya, "Penerapana Metode National Institute of Standars and Technology (Nist) Dalam Analisis Forensik Digital Untuk Penanganan Cyber Crime," Cybersp. J. Pendidik. Teknol. Inf., vol. 4, no. 1, p. 29, 2020, doi: 10.22373/cj.v4i1.7241

[6] R. A. Bintang, R. Umar, and A. Yudhana, "Analisis Media Sosial Facebook Lite dengan tools Forensik menggunakan Metode NIST," Techno (Jurnal Fak. Tek. Univ. Muhammadiyah Purwokerto), vol. 21, no. 2, p. 125, 2020, doi: 10.30595/techno.v21i2.8494.

[7] G. H. A. Kusuma and Y. Fadhilah, "Analisis Forensik Digital E-Commerce pada Website Rental Mobil Menggunakan Metode NIST," Pros. Semin. Nas. SISFOTEK, vol. 3, no. 1, pp. 228-234, 2019.

[8] M. A. Aziz, I. Riadi, and R. Umar, "Alanisis Forensik Line Messenger Berbasis WEB Menggunakan Framework National Institute of Justice (NIJ)," Semin. Nas. Inform. 2018 (semnasIF 2018), vol. 2018, no. November, pp. 51-57, 2018.

[9] M. I. Syahib, I. Riadi, and R. Umar, "Analisis Forensik Digital Aplikasi Beetalk untuk Penanganan Cybercrime Menggunakan Metode NIST," Semin. Nas. Inform., vol. 2018, no. November, p. 134, 2018, [Online]. Available: http://jurnal.upnyk.ac.id/index.php/semnasif/article/view/ 2629.

[10] F. Daryabar, M. H. Tadayon, A. Parsi, and H. Sadjadi, "Automated analysis method for forensic investigation of cloud applications on Android," 2016 8th Int. Symp. Telecommun. IST 2016, pp. 145-150, 2017, doi: 10.1109/ISTEL.2016.7881799.

[11] D. Hariyadi, H. Wijayanto, and I. D. Sari, "Analisis Barang Bukti Digital Aplikasi Paziim Pada Ponsel Cerdas Android Dengan Pendekatan Logical Acquisition," Cybersecurity dan Forensik Digit., vol. 2, no. 2, pp. 1-5, 2019.

[12] R. Umar and Sahiruddin, "Metode Nist Untuk Analisis Forensik Bukti Digital Pada Perangkat Android," Pros. SENDU_U_2019,pp. 978-979, 2019.

[13] I. Riadi, A. Yudhana, M. Caesar, and F. Putra, "1490Article Text-2859-1-10-20190413," Akuisisi Bukti Digit. Pada Instagram Messenger Berbas. Android Menggunakan Metod. Natl. Inst. Justice, vol. 4, pp. 219 227, 2018.

[14] E. Akbal, F. Güneş, and A. Akbal, "Digital Forensic Analyses of Web Browser Records," J. Softw., vol. 11, 
no. 7, pp. 631-637, 2016, doi: 10.17706/jsw.11.7.631637.

[15] R. Saputra and I. Riadi, "Forensic Browser of Twitter based on Web Services," Int. J. Comput. Appl., vol. 175, no. 29, pp. 34-39, 2020, doi: 10.5120/ijca2020920832.

[16] P. W. Setyaningsih, Y. Prayudi, and B. Sugiantoro, "Manajemen Bukti Digital Hasil Akuisisi Dfxml," J. Tek. Inform., vol. 11, no. 1, pp. 47-54, 2018, doi: 10.15408/jti.v11i1.6680.

[17] A. N. Ichsan and I. Riadi, "Mobile Forensic on Androidbased IMO Messenger Services using Digital Forensic Research Workshop (DFRWS) Method," Int. J. Comput. Appl., vol. 174, no. 18, pp. 34-40, 2021, doi: 10.5120/ijca2021921076.

[18] M. Alghizzawi, "The role of digital marketing in consumer behavior: A survey Want more papers like this? The role of digital marketing in consumer behavior: A survey," Int. J. Inf. Technol. Lang. Stud., vol. 3, no. 1, pp. 24-31, 2019, [Online]. Available: http://journals.sfu.ca/ijitls.

[19] M. R. Setyawan, A. Yudhana, and A. Fadlil, "Identifikasi Bukti Digital Skype Di Smartphone Android Dengan Metode National Institute Of Justice ( NIJ )," Semnastek, pp. 565-570, 2019.

[20] F. Iqbal, B. C. M. Fung, M. Debbabi, R. Batool, and A.
Marrington, "Wordnet-Based Criminal Networks Mining for Cybercrime Investigation," IEEE Access, vol. 7, pp. 22740-22755, 2019 , doi: 10.1109/ACCESS.2019.2891694.

[21] W. Naro, A. Syatar, M. M. Amiruddin, I. Haq, A Abubakar, and C. Risal, "Shariah assessment toward the prosecution of cybercrime in indonesia," Int. J. Criminol. Sociol., vol. 9, no. 1, pp. 572-586, 2020, doi: 10.6000/1929-4409.2020.09.56

[22] P. Mali, J. S. Sodhi, T. Singh, and S. Bansal, "Analysing the awareness of cyber crime and designing a relevant framework with respect to cyber warfare: An empirical study," Int. J. Mech. Eng. Technol., vol. 9, no. 2, pp. 110-124, 2018

[23] M. T. Whitty, "Predicting susceptibility to cyber-fraud victimhood," J. Financ. Crime, vol. 26, no. 1, pp. 277292, 2019, doi: 10.1108/JFC-10-2017-0095.

[24] Z. Li, H. Zhang, M. Masum, H. Shahriar, and H. Haddad, "Cyber fraud prediction with supervised machine learning techniques," ACMSE 2020 - Proc. 2020 ACM Southeast Conf., pp. 176-180, 2020, doi: $10.1145 / 3374135.3385296$

[25] T. Pandela and I. Riadi, "Browser Forensics on Webbased Tiktok Applications," Int. J. Comput. Appl., vol. 175, no. 34 , pp. 47-52, 2020, doi: 10.5120/ijca2020920897. 